\title{
天然クロムの $\boldsymbol{\alpha}$ 粒子照射による無担体の ${ }^{54} \mathbf{M n}$ の製法
}

\author{
(1971 年 12 月 17 日受理)
}

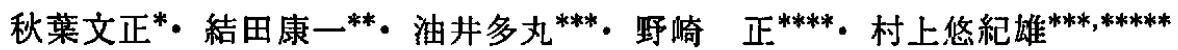

\begin{abstract}
天然クロムに $44 \mathrm{MeV}$ までの $\alpha$ 粒子または ${ }^{3} \mathrm{He}$ 粒子照射を行ない種々の生成核種の昫起曲線，厚いターダット取 率曲線を求めた。すなわち励起曲線によるとその难大は $30 \mathrm{MeV} \alpha$ 粒子で $490 \mathrm{mb}$ にあり， ${ }^{3} \mathrm{He}$ 粒子の $80 \mathrm{mb}$ (18

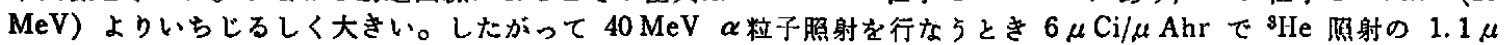

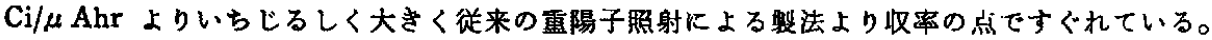

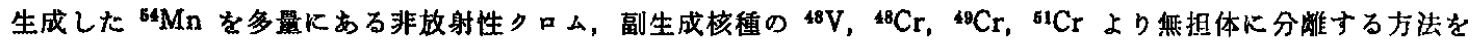

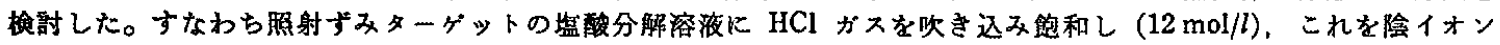
交換樹脂柱にチャージする。12 mol $/ l$ 塩酸で $\mathrm{Cr}^{3+}, \mathrm{V}^{4+}$ を溶崔し、 $\mathrm{Cr}^{3+}$ の䟿色が証められなくなったら $6 \mathrm{~mol} / l$ 程

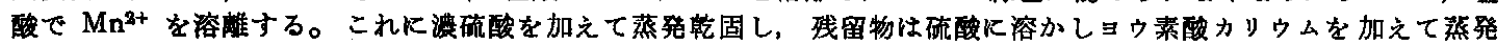
する。そのさい酸性度を $10 \mathrm{~mol} / l$ Kたるつ必要があるので硝酸の共沸点混合組成のガスをたえず吹き込むと無担体 K ${ }^{54} \mathrm{Mn}$ を $100 \mathrm{ml}$ の留出液中に $90 \%$ 回取できることがわかった。留出液は過酸化水素を含む塩酸溶液中で捕集し $\mathrm{Mn}^{2+}$ とした。 $\gamma$ 線スベクトル的にきわめて純粋であることを証めた。
\end{abstract}

\section{1 㒂言}

${ }^{64} \mathrm{Mn}$ は半減期が長く (EC, $T=303$ 日), $r$ 線 $(0.835 \mathrm{MeV}$ 100\%) を放出するので，理工学および農学用トレーサーとして 有用である。

著者らは，クロムをターゲットとして，理化学研究所サイクロ トロンの $\alpha$ おび ${ }^{3} \mathrm{He}$ 粒子（ともに最高 $44 \mathrm{MeV}$ まで）による 照射を行ない、 ${ }^{82} \mathrm{Fe}$ (8.2 時間) の生成々ついて調べたが1)，その 結果 ${ }^{52} \mathrm{Fe}$ と同時に ${ }^{54 \mathrm{Mn}}$ が相当に生成していることがわかった。 ついで天然クロムの 2 と ${ }^{\mathrm{s}} \mathrm{He}$ 照射の場合の ${ }^{54} \mathrm{Mn}$ の励起曲線 を重ね合わせターゲット法で調べたところ，等担体の ${ }^{54} \mathrm{Mn}$ の整 法としては収率が高いことと ${ }^{62} \mathrm{Mn} /{ }^{54} \mathrm{Mn}$ 比の低い製品が得られ る点で $\alpha$ 照射の方が有租であることがわかった。

そこで多量のクロム（价）塩酸溶液からの ${ }^{54} \mathrm{Mn}$ の放射化学的 分離法を検討したところ,イオン交換樹脂法と蒸留法により ${ }^{54} \mathrm{Mn}$ を無担体で放射化学的高純度のすのを分離することができた。し か子従来用いられている ${ }^{51} \mathrm{~V} の(\alpha, 2 n)$ 反応 ${ }^{2)},{ }^{58} \mathrm{Cr} の(d, n)$ または ${ }^{64} \mathrm{Cr}$ の $(d, 2 n)$ 反応 ${ }^{23)},{ }^{56} \mathrm{Fe} の(d, \alpha)$ 反応文なとに よる場合にくらべても十分な量が得られることあわかったので報 告する。しかる， ${ }^{62} \mathrm{Fe}$ を分離した残液から十分な量が得られるの で実用性が高い。

* 弘前大学教育学部, 弘前市文京町

** 農林省 農業技術研究所, 東京都北区西ヶ原

*** 日本原子力研究所ラジオフイントープ研修所, 東京都文京 区本駒込

***** 理化学研究所, 埼玉梃大和町

****** 東京都立大学理学部化学教室, 東京都世田谷区深沢

1) F.Akiha, T.Takeda, T.Aburai, T.Nozaki, Y.Murakami, Radiochim. Acta, 投稿中.

2) J. J. Livingood, G. T. Seaborg, Phys. Rev., 54, 391 (1938).

3) P.Kafalas, J. W. Irvine, Jr., ibid., 104, 703(1956).
2 実

㩆

\section{1 励起曲線の測定}

励起曲線は，重效合わせターダット法により测定した。ターダ ット用のクロム薄板の作製法や照射条件については，すでに報告 したとおりである゙4)。

電着法)によって作製したクロム薄板 $(\phi 30 \mathrm{~mm}, 20 \sim 40 \mathrm{mg}$ ) $\mathrm{cm}^{2}$ ) を通常 10〜12 枚重水合わせて，照射粒子の飛程に対して 十分に “thick-target”として照射した。照射は, 理化学研究所 サイクロトロン $(160 \mathrm{~cm}$, 可変エネルギー型)を租用し， $\alpha$ およ び ${ }^{3} \mathrm{He}$ 粒子ともに最高 $44 \mathrm{MeV}$ まで，0.5〜1 $\mu \mathrm{A}$ のビームで照 射したが，発熱その他によるターゲットの損傷は認められなかっ た。

费験では，ターゲットとして比較的厚いクッム薄板を用いてい るので，反応断面積と照射粒子ェネルギーとの関係はヒストグラ ムの形で得られる。 $\alpha,{ }^{\mathrm{s}} \mathrm{He}$ 照射ともに，それぞれ数回の実験で 得られたヒストグラムから常法のように励起曲線を求めた。いず れの場合も，クロム薄板の厚さを $30 \mathrm{mg} / \mathrm{cm}^{2}$ 前後としたので数 回の実験で得られたヒストグラムの形は，ほぼよく一致した。

放射能測定は, 3 in $\times 3$ in $\mathrm{NaI}(\mathrm{Tl})$ 結晶とマルチチャンネル波 高分析器, 2 in $\times 2$ in $\mathrm{NaI}(\mathrm{Tl})$ 結晶とシングルキャンネル波高分 析器で測定した。あらかじめ X-r 同時計数法でその崩犊数を定 めた ${ }^{64} \mathrm{Mn}$ 校正用線源との比较法により ${ }^{54} \mathrm{Mn}$ の生成量を湘定し た。照射すみターゲットから ${ }^{52} \mathrm{Fe}$ を分離したのらの新しい試料 では，主として ${ }^{62} \mathrm{Mn}(\gamma \quad 0.744,0.935,1.434 \mathrm{MeV})$ の妨害の ためスペクトルの解析が困難であったが，これらの共存放射能が 十分に滅衰した試料では正確な測定が可能であった。

一方, $\mathrm{Ge}(\mathrm{Li})$ 半瓷体検出器 $(23 \mathrm{ml})$ と波高分析器を組又合わ せて，照射ずみターゲットに生じた RI の生成放射能の非破填測 定を行なった。あらかじめて線用標準線源（IAEA 険定）を用い て效率曲線を求めたところ， $r$ 線エネルギー0.1〜2 MeV の䈥围

4) 秋葉文正，村上悠紀蜼，日本原子力学会誌，12，382(1970). 
でよい直線性を示した。この計数効率曲線を利用して ${ }^{54} \mathrm{Mn}$ その 他の主要な生成核種の生成量 ( $\mu \mathrm{Ci}$ 数) を求めた。そのさい,そ れぞれの核種のて線エネルギーと1崩壞あたりの放出割合なと， 計算に必要な核データは “Table of Isotopes”る) を参照した。た たし，照射ずみターゲットは 30〜60 分の冷却時間を扣いて湘定 したので，半減期のきわめて短い核種は測定から除かれている。

用いた標华線源の核種，放射能強度（信頼度 95\%の精㳙）は それぞれつぎのと括りである。検定日はいずれる1971 年 1 月 1 日 00.00 標準時である。

${ }^{57} \mathrm{Co} 10.65 \mu \mathrm{Ci}( \pm 1 \%) ;{ }^{22} \mathrm{Na} 10.31 \mu \mathrm{Ci}( \pm 0.9 \%) ;{ }^{177} \mathrm{Cs}$ $10.28 \mu \mathrm{Ci}( \pm 1.3 \%) ;{ }^{64} \mathrm{Mn} 10.62 \mu \mathrm{Ci}( \pm 1.0 \%) ;{ }^{60} \mathrm{Co} 10.62$ $\mu \mathrm{Ci}( \pm 0.6 \%) ;{ }^{88} \mathrm{Y} 10.24 \mu \mathrm{Ci}( \pm 1.3 \%)$

\section{2 製造用ターゲットの作製と照射}

製造用ターゲットは銅板 $(5 \times 9 \times 1 \mathrm{~cm})$ 上に電着法によって約 $2 \times 7 \times 0.5 \mathrm{~cm}$ のクロム金属を析出させたるのを朋いだ。この寸 法は理化学研究所サイクロトロンにおける RI ターダットの一つ の規格である。このターゲットを銅板の襄面から水で冷却しなが ら，サイクロトロンにより 40〜 44 MeV の $\alpha$ 粒子で 1 5 時間照 射した。 $\alpha$ 粒子束は得られる最高（サイクロトロンの調子によっ ても異なるが，最大 $30 \mu \mathrm{A} ）$ にしたときも，ターゲットの熱伝導 性が良好であるため，発熱による損傷は照射後まったく認められ なかった。

\section{3 化学分離法の検討}

上記のターゲットを照射後に程酸分解した溶液には7)8, 別に分 離した ${ }^{82} \mathrm{Fe}$ のほか，多量の非放射性クロムとともにクロムから 生じた ${ }^{48} \mathrm{Cr},{ }^{49} \mathrm{Cr},{ }^{51} \mathrm{Cr}\left(\mathrm{Cr}^{9+}\right),{ }^{62} \mathrm{Mn},{ }^{54} \mathrm{Mn},{ }^{56} \mathrm{Mn}\left(\mathrm{Mn}^{2+}\right)$ お よび ${ }^{48} \mathrm{~V}\left(\mathrm{~V}^{4+}\right)$ などが含まれる。しかし，幸いに ${ }^{5 \mathrm{Mn}}$ の半減 期がもっとも長いので，その化学分䧹は，短半減期の同位体 ${ }^{36} \mathrm{Mn}$ (2.576 時間) や $52 \mathrm{Mn}$ (5.7 日) などの放射能を減衰させたのち に行なった。共沈法, 溶媒抽出法などす考慮したが結局, イオン 交換樹脂法 ${ }^{910)}$, 蒸留法"1)の併用法について種々検討した。

2.3.1 险イオン交換法：クロム,バナ゙ジウムとマンガンを錯陰 イオンとして分䧺することとし，陰イオン交换樹脂 (Amberlite

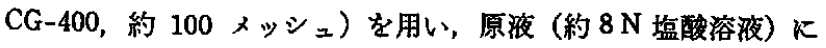
塩化水素を吹き込及 $10 \sim 12 \mathrm{~mol} / l$ の塩酸溶液としたのち, あら かじめ $12 \mathrm{~mol} / l$ 塩酸で処理した樹脂柱を通過させ,つついて 12 $\mathrm{mol} / l$ 塩酸を流して $\mathrm{Cr}^{3+}$ と $\mathrm{V}^{4+}$ を洗い出す。流出液に $\mathrm{Cr}^{3+}$ の 緑色が認められなくなったところで溶離液として $6 \mathrm{~mol} / l$ 塩酸を 用い $\mathrm{Mn}^{2+}$ を溶離する。このとき, $\mathrm{Mn}^{2+}$ と他のイオンの分崔係 数の值には大差がないため，完全分離がもずかしく，カラムの大

5) C.M. Lederer, J.M. Hollander, I. Perlman, "Table of Isotopes", 6 th Ed,, Wiley, New York(1968).

6）クロムのついていない銅板の部分は銀ハッキしてあり，乙 たがって塩酸溶解のさい銅板からの生成放射能の混入はな いようにしてある。

7) 秋蒋文正，村上悠紀雄，日本分析化学会誌，21，1530(1970).

8）秋藮文正，油井多丸，野绮 正，村上悠紀雄, Radioisotopes, 21, 155(1972).

9) W.W.Meinke, O.Anders, Dept.Chem. Univ. of Michigan, Progress Rept., 4, 49(1955).

10) K. A. Kraus, F. Nelson, Proc. Intern. Conf. Peaceful Use At. Energy, 7, 113(1956).

11) J.D. H. Strickland, G.Spicer, Anal.Chim. Acta, 3, 543 (1949).
きさを内径 $1.25 ， 1.70,2.75 ， 3.20 \mathrm{~cm}$ ，樹脂量を $25 \sim 170 \mathrm{~g}$ ， カラムの長さを 38〜 $61 \mathrm{~cm}$, 流速, ク口A（III）溶液の濃度を変 えるなど種々と試みたが，マンガン区分にはとらしてすクロムが 残った。また，2回くり返したときマンガン区分には樹脂の分解 生成物とみられる固形分が望められた。

2.3.2 蒸留法：こらしてあらかじ陰イオン交換法で大部分 の $\mathrm{Cr}^{3+}$ と $\mathrm{V}^{4+}$ を除いた試料について、 マンガンの蒸留法を検 討した。すなわち，マンガン区分の塩酸溶液 $(6 \mathrm{~mol} / l)$ に漕硫酸 $20 \mathrm{~m} l$ を加えて点発乾固して塩化物イオンを完全に除きこれを $10 \mathrm{~mol} / l$ 硫酸 $50 \mathrm{ml}$ とともに $200 \mathrm{ml}$ の蒸留フラスコに移し, ヨウ素酸カリウム $2 \mathrm{~g}$ を加えて加熱蒸留し，166 $\mathrm{C}$ の留分をとっ た。硫酸の濃度は $10 \mathrm{~mol} / l$ Kたるつ必要があり, $10 \mathrm{~mol} / l$ 以上 ではマンガンの留出は急激に起こり難くなる。このため原報11)で は, $40 \mathrm{vol} \%$ の硝酸溶液を毛細管を通じて 硫酸溶液中に注意し て徐々に滴下しているが，ときどき突沸が起こるので，共沸点 $\left(120.5^{\circ} \mathrm{C}\right)$ の硝酸蒸気を徐々に吹き込む方法がよりすぐれている ことを知った。原報の方法では留出液 $250 \sim 300 \mathrm{ml}$ で約 90\%の マンガンを蒸留できたが，この改良法では留出液約 $100 \mathrm{ml}$ でほ とんど定量的にマンガンが回收され，しかすその放射化学的純度 はきわめて高く満足すべきすのであった。

留出液は過酸化水菜水数 $\mathrm{m} i$ と少量の塩酸を加えた受器に捕集 し， $\mathrm{Mn}_{2} \mathrm{O}_{7}$ をふたたび $\mathrm{Mn}^{2+}$ に還元する。この溶液を蒸発乾固 したところ，固形物残留物は汇とんど認められなかった。なお， 留出液に過酸化水㩰たりを加点て蒸発乾固するときは，無担体状 態では蒸散によりかなりの量のマンガンが損失するので注意を要 する。

イオン交換法をやめ，はじめから蒸留法によるとマンガンとと もに少量のクロムの留出がまぬがれない。したがって, 両者の併 用法を用いることにした。全操作を通じての ${ }^{54} \mathrm{Mn}$ の収率は $90 \%$ 以上であった。

\section{3 实験結果と考案}

\section{1 照射ずみターゲットの 線スベクトル}

図 1〜3に重ね合わせ，照射したクロムターゲットの非破壤 $r$ 線スベクトルを示す。図1のスペクトルは， $\alpha$ 粒子 $(44 \mathrm{MeV})$ の 照射終了時から約 1.5 時間後に半䢙体検出器で湘定したもので, 試料のターゲットは $\alpha$ 粒子エネルギー $36 \sim 34 \mathrm{MeV}$ の照射に相 当する部分である。図2には ${ }^{3} \mathrm{He}$ 粒子 (40.4 37.2 MeV) で照 射したダーゲットを3.5時間冷却し，半導体検出器で眼定した結 果を示す。また，図 3 K, ${ }^{3} \mathrm{He}(\sim 26 \mathrm{MeV})$ 照射試料の測定結果 を示すが, スペクトルの番号 1〜7 は照射方向からのターゲット

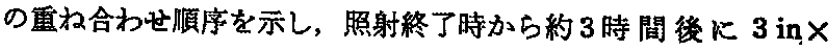
3 in $\mathrm{NaI}$ 検出器で洞定した。また， $\alpha$ 粒子 $(36 \sim 33 \mathrm{MeV})$ 照射 ずみターゲットの塩酸溶解溶液より ${ }^{52} \mathrm{Fe}$ を抽出分離した残りの 溶液について残存放射能を測定したスペクトルの時間的变化を図 4 に示す。

これらのスペクトルにみられるよらに，もっとも多量化生成す る放射能は， $\alpha$ 照射では ${ }^{49} \mathrm{Cr},{ }^{56} \mathrm{Mn}$ であり, ${ }^{8} \mathrm{He}$ 照射では ${ }^{40} \mathrm{Cr}$, 52Mn などである。このほか， ${ }^{51} \mathrm{Cr}$ は两方の照射でかなりの異を 生ずるが, ABV はいずれの照射でるかずかしか生していない。

\section{$3.2{ }^{64} \mathrm{Mn}$ の钧起曲線}

励起曲線の洞定結果は, 图 5 および図 6 に示す。また, 表 1 に 


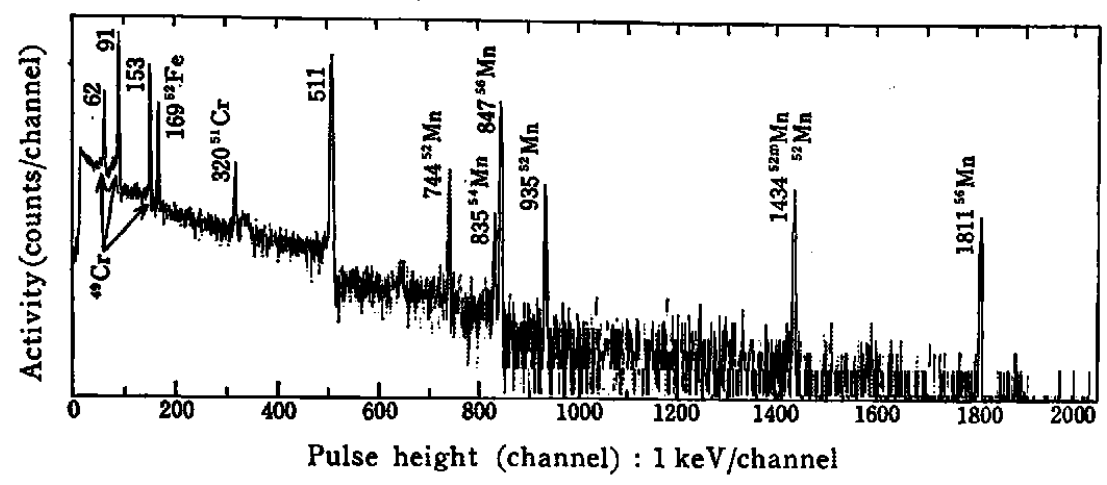

Fig. $1 \gamma$-Ray spectra by $\mathrm{Ge}(\mathrm{Li})$ spectrometer for $\alpha$-bombarded target plate of chromium after $1.5 \mathrm{hrs}$ cooling
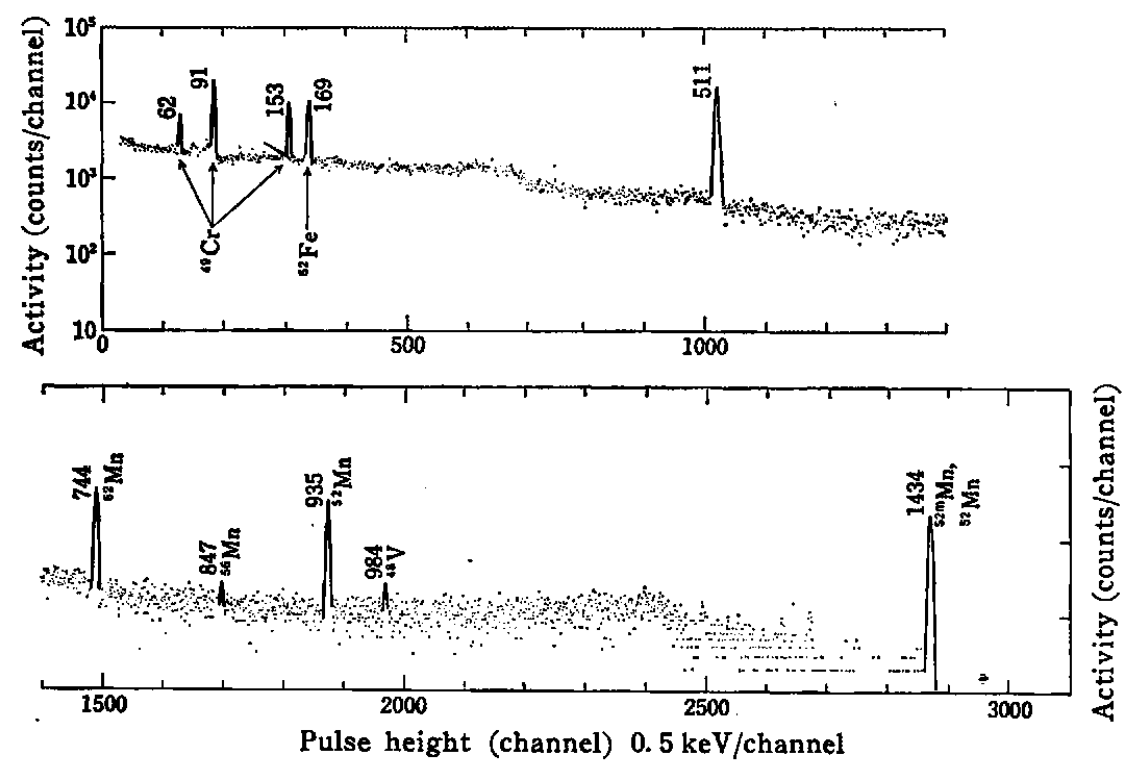

Fig. $2 \boldsymbol{r}$-Ray spectra by $\mathrm{Ge}(\mathrm{Li})$ spectrometer for ${ }^{\text {sHe-bombarded target }}$ plate of chromium after $3.5 \mathrm{hrs}$ cooling

Table 1 Nuclear data of manganese isotopes formed by $\alpha$ and sHe reactions on chromium

\begin{tabular}{|c|c|c|c|c|}
\hline $\begin{array}{l}\text { Product } \\
\text { nuclide }\end{array}$ & Formation reaction & $\begin{array}{c}Q \text {-Value } \\
(\mathrm{MeV})\end{array}$ & $\begin{array}{c}\text { Threshold } \\
(\mathrm{MeV})\end{array}$ & $\begin{array}{l}\text { Half life, } \\
\text { mode of decay }\end{array}$ \\
\hline${ }^{52} \mathrm{Mn}$ & $\begin{array}{l}{ }^{60} \mathrm{Cr}(\alpha, p n) \\
{ }^{60} \mathrm{Cr}\left({ }^{s} \mathrm{He}, p\right) \\
{ }^{50} \mathrm{Cr}\left({ }^{3} \mathrm{He}, p 2 n\right)\end{array}$ & $\begin{array}{r}-12.48 \\
+\quad 8.10 \\
-13.20\end{array}$ & $\begin{array}{c}13.48 \\
0 \\
13.97\end{array}$ & $\begin{array}{c}5.7 \mathrm{~d} \\
\beta^{+}(3.4 \%), \quad \operatorname{EC}(56 \%) \\
\gamma 0.744, \quad 0.935, \quad 1.434\end{array}$ \\
\hline${ }^{6 *} \mathrm{Mn}$ & $\begin{array}{l}{ }^{82} \mathrm{Cr}(\alpha, p n) \\
{ }^{8} \mathrm{Cr}(\alpha, p 2 n) \\
{ }^{62} \mathrm{Cr}\left({ }^{8} \mathrm{He}, p\right) \\
{ }^{59} \mathrm{Cr}\left({ }^{3} \mathrm{He}, p n\right) \\
{ }^{54} \mathrm{Cr}\left({ }^{3} \mathrm{He}, p 2 n\right)\end{array}$ & $\begin{array}{l}-12.79 \\
-20.74 \\
+7.79 \\
-0.16 \\
-9.88\end{array}$ & $\begin{array}{c}13.78 \\
22.30 \\
0 \\
0.17 \\
10.48\end{array}$ & $\begin{array}{l}303 \mathrm{~d} \\
\mathrm{EC}, \text { no } \beta^{+}, \text {no } \beta^{-} \\
\gamma 0.835\end{array}$ \\
\hline${ }^{86} \mathrm{Mn}$ & $\begin{array}{l}{ }^{58} \mathrm{Cr}(\alpha, p) \\
{ }^{64} \mathrm{Cr}(\alpha, p n) \\
{ }^{*} \mathrm{Cr}\left({ }^{s} \mathrm{He}, p\right)\end{array}$ & $\begin{array}{r}-3.25 \\
-12.97 \\
+7.07\end{array}$ & $\begin{array}{l}3.49 \\
13.93 \\
0\end{array}$ & $\begin{array}{c}2.576 \text { h } \\
\beta^{-}, \gamma 0.847,1.811,2.12\end{array}$ \\
\hline
\end{tabular}

は,クロムの $\alpha$ および ${ }^{3 \mathrm{He}}$ 照射によるマンガンの放射性同位体の 生成反応と反応 $Q$ 値，しきい值，核的性貿を示す。

$\alpha$ 反応の励起曲線は $30 \mathrm{MeV}$ 付近で極大値 $490 \mathrm{mb}$ を示す。 天然ク口ムの同位体存在比中反応Q值なとからみても明らかなよ $5 k, \alpha$ 照射飞よる ${ }^{54} \mathrm{Mn}$ の生成は主として ${ }^{82} \mathrm{Cr}(\alpha, p n)^{54} \mathrm{Mn}$ と ${ }^{58} \mathrm{Cr}(\alpha, p 2 n)^{64} \mathrm{Mn}$ の二つの反応の寄与によるるのである。
${ }^{3} \mathrm{He}$ 反応の励起曲線は $18 \mathrm{MeV}$ 付近で極大值 $80 \mathrm{mb}$ を示す。 この場合， ${ }^{84} \mathrm{Mn}$ の生成飞は ${ }^{62} \mathrm{Cr}\left({ }^{3} \mathrm{He}, p\right){ }^{64} \mathrm{Mn}$ と ${ }^{88} \mathrm{Cr}\left({ }^{3} \mathrm{He}, p n\right)$ ${ }^{54} \mathrm{Mn}$ の二つの反応か関係している。

\section{3 收率 (Thick-target yields)}

$\alpha$ および ${ }^{8} \mathrm{He}$ 反応による ${ }^{54} \mathrm{Mn}$ 坐成の収率曲線を图 7 亿示す。 上記の励起曲線恃重初合わせターダット法で籼定しているので, 


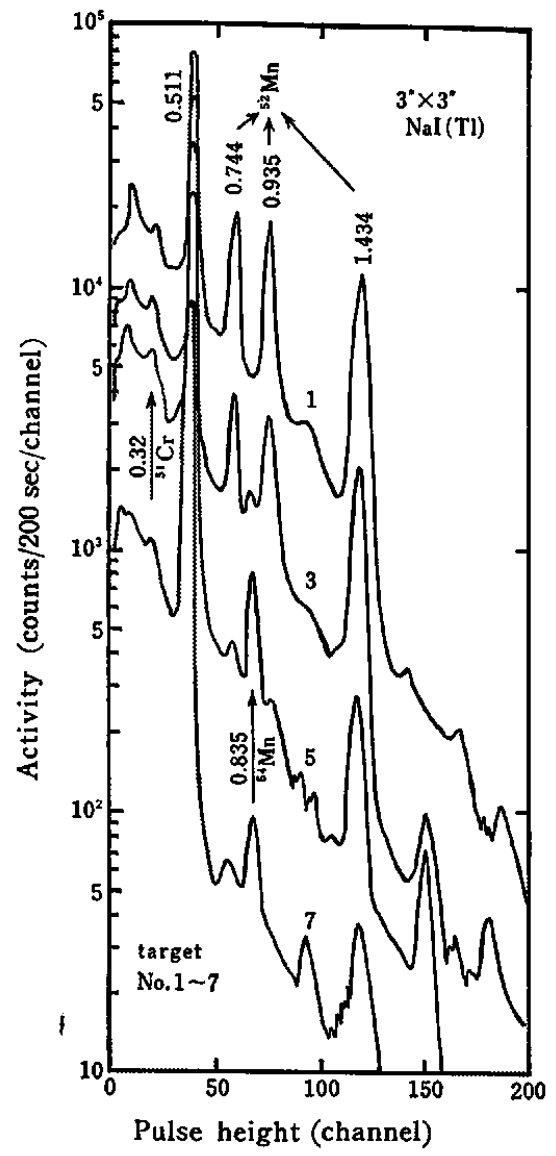

Fig. $3 r$-Ray spectra of stacked chromium targets bombarded with $\sim 26 \mathrm{MeV}$ sHe-particles, observed after about 3 hrs cooling

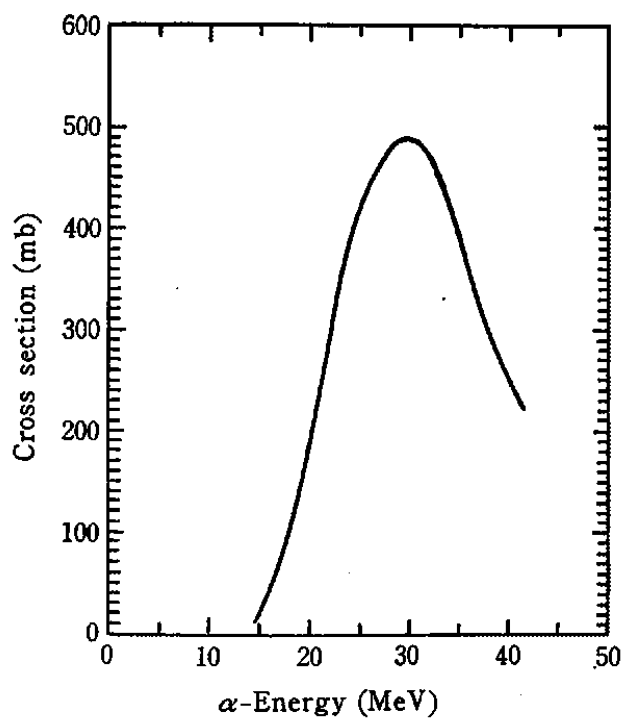

Fig. 5 Excitation curve for the ${ }^{62,58} \mathrm{Cr}+$ $\alpha \rightarrow{ }^{54} \mathrm{Mn}$ reactions

各ターゲットの入射粒子エネルギーに対応する ${ }^{54} \mathrm{Mn}$ の全生成量 すなわち，収率 (Thick-target yields, $\mu \mathrm{Ci} / \mu \mathrm{Ahr}$ )を求め，こ れをエネルギー唃に対してブロットすることによりこの曲線を得 た。 $40 \mathrm{MeV}$ で $1 \mu \mathrm{Ahr}$ の照射終了時に猢收率怯， $\alpha$ 照射 で $6 \mu \mathrm{Ci}$, ง $\mathrm{He}$ 照射で $1.1 \mu \mathrm{Ci}$ である。天然クロムの重陽子

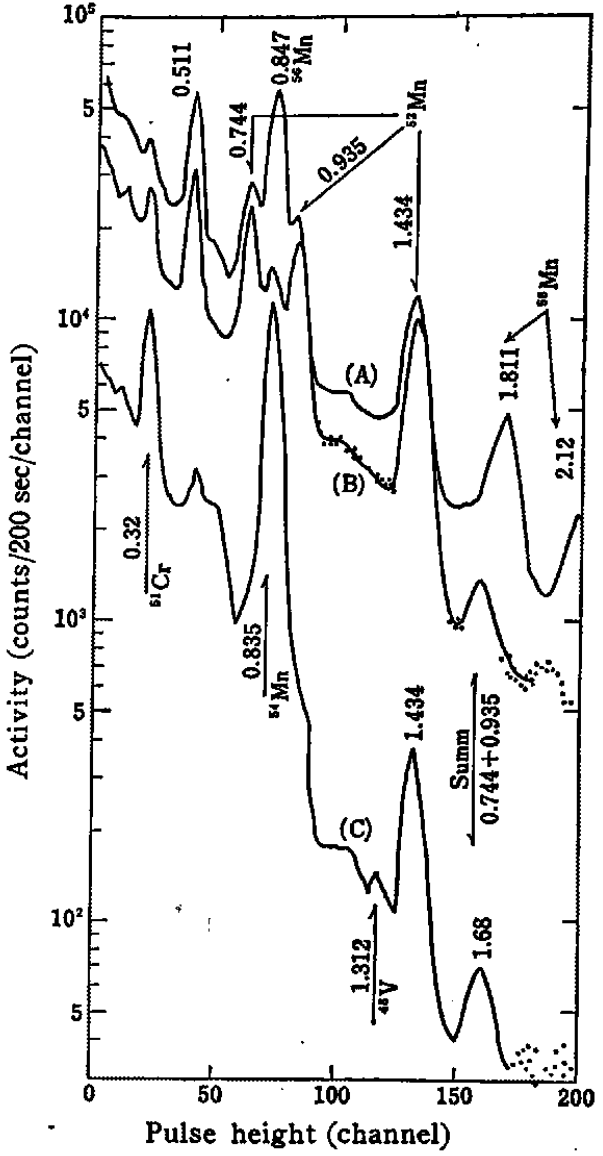

Fig. $4 r$-Ray spectra of $\mathrm{HCl}$ solution of bombarded $\mathrm{Cr}$-target, observed at various intervals after removal of ${ }^{62} \mathrm{Fe}$

Curves (A), (B) and (C) were measured at $6.5 \mathrm{hrs}$, $30 \mathrm{hrs}$ and 30 days after the end of $\sim 40 \mathrm{MeV} \alpha$-bombardment, respectively

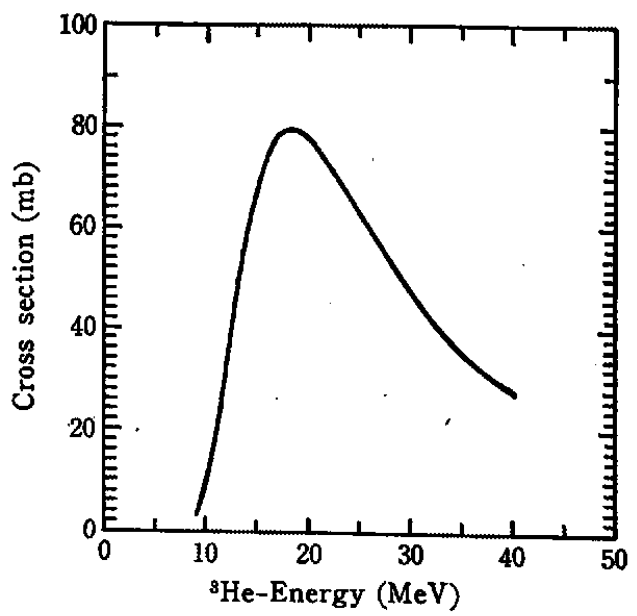

Fig. 6 Excitation curve for the ${ }^{52,58} \mathrm{Cr}+$ ${ }^{3} \mathrm{He} \rightarrow{ }^{64} \mathrm{Mn}$ reactions

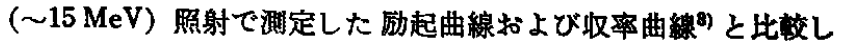
てみると, $1.3 \mu \mathrm{Ci} / \mu \mathrm{Ahr}$ で ${ }^{82} \mathrm{Mn} /{ }^{54} \mathrm{Mn}$ は 14 15 MeV の重陽 子照射で 99 111 で $\alpha$ 照射にくらべて ${ }^{22} \mathrm{Mn}$ が莫大で 8〜9 半 減期以上たたないと ${ }^{54} \mathrm{Mn}$ の量以下とならない不利がある。ま

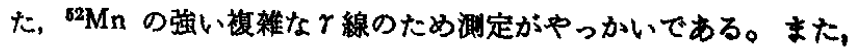




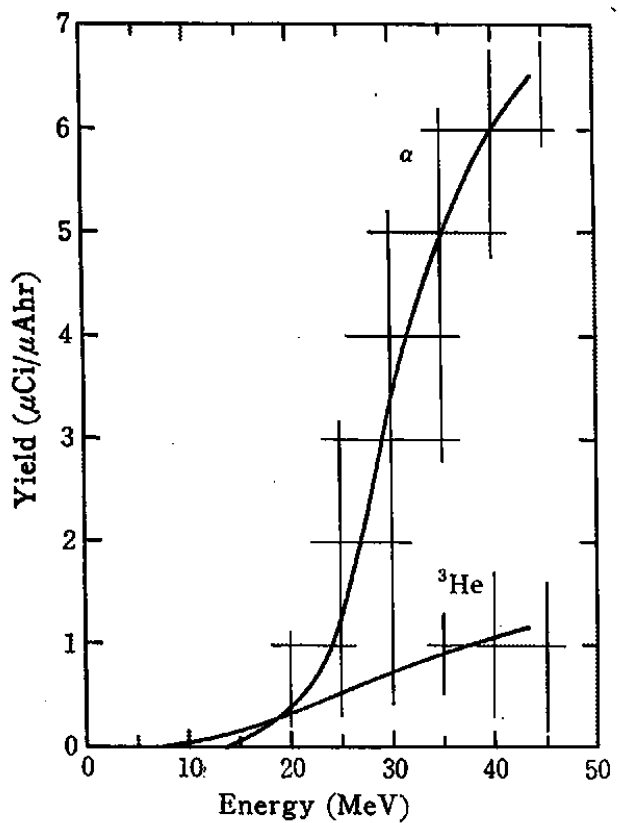

Fig. 7 Thick-target yield curves for the ${ }^{52,58} \mathrm{Cr}+$ $\alpha \rightarrow{ }^{54} \mathrm{Mn}$ and ${ }^{52,59} \mathrm{Cr}+{ }^{3} \mathrm{He} \rightarrow{ }^{54} \mathrm{Mn}$ reactions

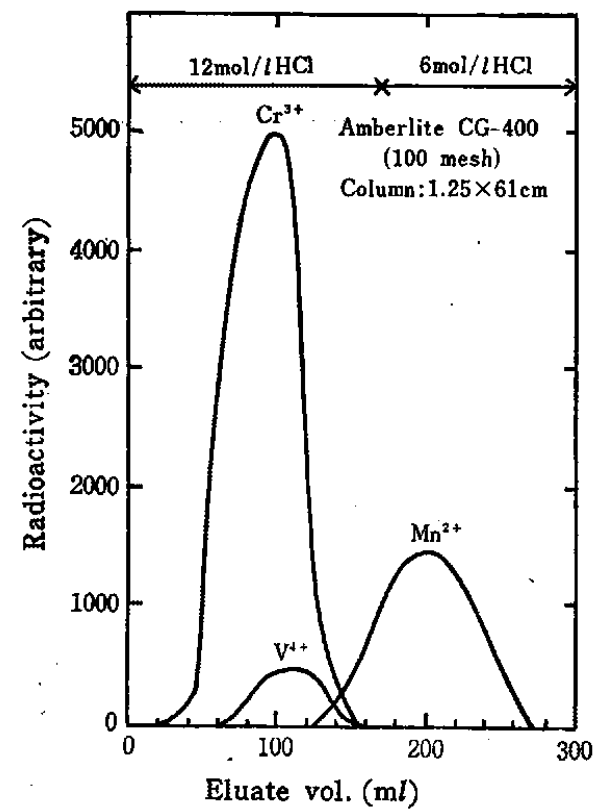

Fig. 8 Separation of $\mathrm{V}^{4+}, \mathrm{Cr}^{3+}$ and $\mathrm{Mn}^{2+}$ by anion exchange method

$40 \mathrm{MeV}$ の重陽子照射による ${ }^{54} \mathrm{Mn}$ の生成量は約 $2 \mu \mathrm{Ci} / \mu \mathrm{Ahr} く く$ らいと考兄られるから，天然クロムの いることがわかる。つぎK， ${ }^{88} \mathrm{Fe}$ ならびに ${ }^{85} \mathrm{Cr}$ の重陽子（ 5.5 $\mathrm{MeV})$ 照射, ${ }^{51} \mathrm{~V} の \alpha$ 粒子 $(16 \mathrm{MeV})$ 照射による ${ }^{64} \mathrm{Mn}$ の収率

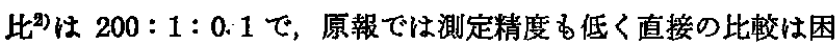
難であるが， ${ }^{66} \mathrm{Fe}$ の重陽子照射以外は収率が低くて実用性のない ことがわかった。

\section{4 化学分離法ならびに放射化学的純度}

${ }^{54} \mathrm{Mn}$ の化学分離には陰イオン交換法と 蒸留法を併用したが， r線スペクトロメトリーによる溶離曲線の測定例を図 8 に示す。 实際には，照射ずみターダットの塩酸溶液 $(8 \mathrm{~N})$ から ${ }^{52} \mathrm{Fe}$ を

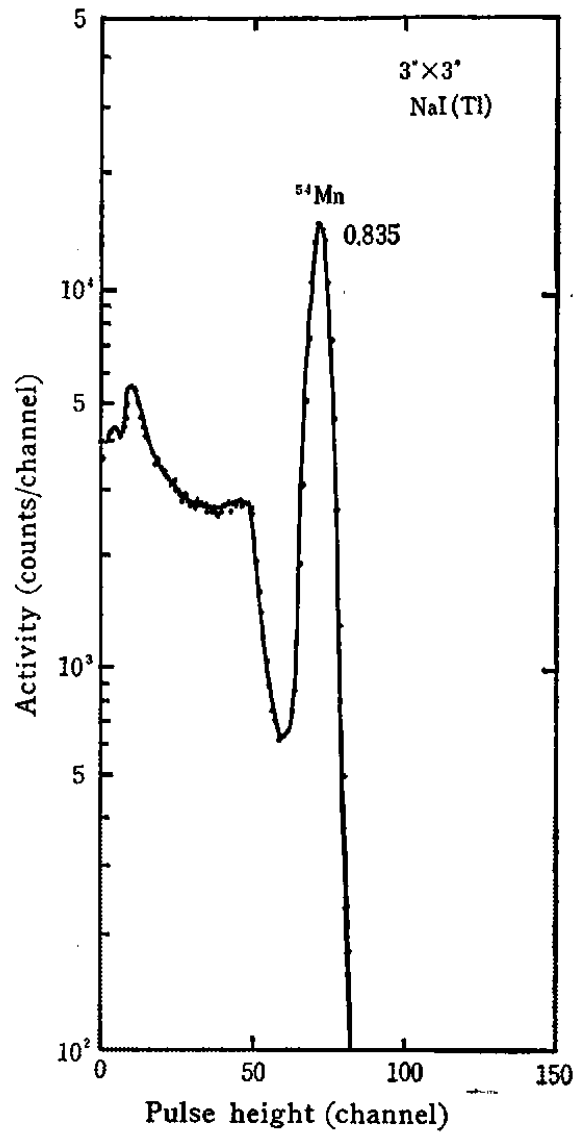

Fig. $9 r$-Ray spectrum of ${ }^{84} \mathrm{Mn}$

Table 2 Thick-target yields of ${ }^{62} \mathrm{Mn}{ }^{54} \mathrm{Mn}$ and ${ }^{56} \mathrm{Mn}$ for $\alpha$ and ${ }^{\mathrm{s}} \mathrm{He}$ reactions on natural chromium.

Yields : $\mu \mathrm{Ci} / \mu \mathrm{Ahr}$ at $40 \mathrm{MeV}$ incident energy

\begin{tabular}{|c|c|c|c|c|}
\hline React. $\quad$ Nuclide & ${ }^{52} \mathrm{Mn}$ & ${ }^{54} \mathrm{Mn}$ & ${ }^{68} \mathrm{Mn}$ & $\begin{array}{c}{ }^{52} \mathrm{Mn} /{ }^{54} \mathrm{Mn} \\
\text { ratio }\end{array}$ \\
\hline$\alpha$ & 22 & 6.0 & 185 & 3.7 \\
\hline${ }^{3} \mathrm{He}$ & 156 & 1.1 & 47 & 142 \\
\hline
\end{tabular}

分離した残りの溶液または照射ずみターゲットの塩酸溶解溶液に ボンベから塩化水索を吹き込んで飽和させたのち，Amberlite CG-400 (約 100 メッシュ) のカラム $(\phi 3.2 \mathrm{~cm} \times 38 \mathrm{~cm})$ を流 速 $1 \mathrm{~m} l / \mathrm{min}$ で通し，つづいて $12 \mathrm{~mol} / l$ 塩酸で, $\mathrm{V}^{4+}, \mathrm{Cr}^{3+}$ を 洗い出し， $6 \mathrm{~mol} / l$ 塩酸で $\mathrm{Mn}^{2+}$ を溶離した。マンガン区分は約 $500 \mathrm{ml}$ ぐらいで少量のバナジウム，クロムの放射性不純物を含 む。これらの不純物は，引きつついて2.3.2で述べた蒸留法によ り完全に除かれた。こうして，rスペクトル的に䋘粋な ${ }^{54} \mathrm{Mn}$ を 無担体で 90\% 以上の収率を得た。その 示す。

また, ${ }^{54} \mathrm{Mn}$ の放射化学的純度に 関係するのは主として半減期 5.7 日の ${ }^{62} \mathrm{Mn}$ の存在である。 ${ }^{54} \mathrm{Mn}$ と同時に生成する ${ }^{52} \mathrm{Mn}$ お。 よび ${ }^{66} \mathrm{Mn}$ の取率を表 2 に示す。 $\alpha,{ }^{8} \mathrm{He}$ 粒子とすに $40 \mathrm{MeV}$ の 照射終了時における ${ }^{62} \mathrm{Mn} /{ }^{5} \mathrm{Mn}$ 比の值は, これら実浿の結果 $\alpha$ 照射で $\simeq 3.7,{ }^{3} \mathrm{He}$ 照射で $\simeq 142$ であり，この点からみても $\alpha$ 照射の方が有租である。 ${ }^{66} \mathrm{Mn}$ は $\alpha$ 照射の方が ${ }^{8} \mathrm{He}$ 照射の約 4 倍 だけ多く生ずるが，半減期が 2.576 時間と短いので実用上は問題 とならない。 
終りに本研究にあたり実駼上の便宜を与えられた理化学研究所 主任研究員玟滕信房博士，ならびに理研サイクロトロングループ
の各位に深く感謝いたします。

(1971 年 4 月，日本化学会第 24 年会 (一部) 発表)

\title{
Production of Carrier-free ${ }^{54} \mathrm{Mn}$ by the $\alpha$-Particle Bombardment of Natural Chromium
}

\author{
Fumimasa Akina*, Koichi Yurta**, Tamaru Aburai***, \\ Tadashi Nozaki*** and Yukio Murakami***** \\ * Faculty of Education, Hirosaki University; Bunkyo-cho, Hirosaki-shi, Japan \\ ** National Institute of Agricultural Science, M.A.E. ; Nishigahara, Kita-ku, Tokyo, Japan \\ *** Radioisotope School, Japan Atomic Energy Research Institute; Honkomagome, \\ Bunkyo-ku, Tokyo, Japan \\ **** The Institute of Physical and Chemical Research; Yamato-machi, Saitama, Japan \\ ***** Radioisotope School, Japan Atomic Energy Research Institute : Department of Chemistry, \\ Faculty of Science, Metropolitan University; Fukazawa, Setagaya-ku, Tokyo, Japan
}

For the production of ${ }^{54} \mathrm{Mn}$ by the $\alpha$ - and ${ }^{5} \mathrm{He}$-particle reactions on natural chromium, their excitation curves and thick-target yields were measured. Also various conditions in the production procedure, especially the chemical separation of manganese in a hydrochloric acid solution of the bombarded target after the removal of ${ }^{62} \mathrm{Fe}$ were examined. A stack of thin chromium plates was bombarded by $\alpha$ - or ${ }^{3} \mathrm{He}$-particles beam of $44 \mathrm{MeV}$ maximum energy, and the manganese activities were measured nondestructively or after the chemical separation.

The excitation curve of the $\alpha$-reaction shows a maximum of $490 \mathrm{mb}$ near $30 \mathrm{MeV}$ energy, and that of the ${ }^{3} \mathrm{He}$-reaction, a maximum of $80 \mathrm{mb}$ near $18 \mathrm{MeV}$. The thick-target yields for $40 \mathrm{MeV}$ incident energy are $6 \mu \mathrm{Ci} / \mu \mathrm{Ahr}$ and $1.1 \mu \mathrm{Ci} / \mu \mathrm{Ahr}$ for the $\alpha$-reaction and the ${ }^{8} \mathrm{He}-$ reaction, respectively. The $\alpha$-reaction thus proved to give a higher yield of ${ }^{54} \mathrm{Mn}$ than the other possible reactions.

The bombarded chromium target was dissolved in a hydrochloric acid solution $(8 \mathrm{~N})$ from which the ${ }^{62} \mathrm{Fe}$ was removed by an extraction method. The remaining solution was saturated with a pure $\mathrm{HCl}$ gas in such a way to bubbling it through the solution, from which almost all the non-radioactive chromium and other byproduced active contaminants were removed by an anion exchange method. The manganese solution thus obtained was evaporated to dryness, and the $\mathrm{Cl}^{-}$-free residue was dissolved in $50 \mathrm{ml}$ of $10 \mathrm{~mol} / l \mathrm{H}_{2} \mathrm{SO}_{4}$ together with $2 \mathrm{~g}$ of $\mathrm{KIO}_{3}$. And then from the resulting solution the $\mathrm{Mn}$ was distilled out as $\mathrm{Mn}_{2} \mathrm{O}_{7}$ into a trap containing a small amounts of dilute $\mathrm{HCl}$ solution plus $\mathrm{H}_{2} \mathrm{O}_{2}$. To maintain the solution at $10 \mathrm{~mol} / \mathrm{l}$ of sulfuric acid concentration and $166^{\circ} \mathrm{C}$ which is the optimum conditions for distillation, azeotropic nitric acid vapour $\left(120.5^{\circ} \mathrm{C}\right)$ was added gradually into the boilling solution. The ${ }^{54} \mathrm{Mn}$ was obtained in carrier-free state. The chemical yields over all the chemical procedure proved to be $>90 \%$ with a sufficient radiochemical purity.

The production method of ${ }^{84} \mathrm{Mn}$ via the $\alpha$-reactions on natural chromium proved to be superior in higher yields and some other reasons to other possible reactions. 